\title{
Good University Governance dan Internasionalisasi Program Studi: Studi Kasus pada 2 (Dua) Program Studi di Perguruan Tinggi Negeri (PTN) dan Perguruan Tinggi Muhammadiyah (PTM)
}

\author{
Dyah Mutiarin $^{a}$ *, Suswanta ${ }^{\text {a }}$, Awang Darumurti ${ }^{\text {a }}$ \\ ${ }^{a}$ Universitas Muhammadiyah Yogyakarta, Daerah Istimewa Yogyakarta, Indonesia
}

\section{INFORMASI ARTIKEL}

Article history:

Dikirim tanggal: 14 November 2018

Revisi pertama tanggal: 16 November 2018

Diterima tanggal: 30 Juli 2019

Tersedia online tanggal: 22 Agustus 2019

Keywords: good university governance, department internationalization, internationlization strategy

\begin{abstract}
Good University Governance (GUG) is very relevant to the internationalization of any university and its department. This study compares the strategy of Department of Government Science - Muhammadiyah University of Yogyakarta (UMY), and the Department of Public Policy and Management - Gadjah Mada University (UGM). The research method used is a qualitative approach with the process of collecting data using interview techniques, documentation, observation and Focus Group Discussion (FGD). The results of this research can be seen, the variation of GUG results in encouraging internationalization, namely: focus on international reputation, focus on international networking, and focus on global branding.
\end{abstract}

\section{INTISARI}

Good University Governance (GUG) sangat relevan dengan upaya internasionalisasi yang dilakukan universitas dan program studi dibawahnya. Penelitian ini mengkomparasikan strategi GUG dalam internasionalisasi Prodi Ilmu Pemerintahan Universitas Muhammadiyah Yogyakarta (UMY) dan Prodi Manajemen dan Kebijakan Publik, Universitas Gadjah Mada (UGM). Metode penelitian yang digunakan adalah pendekatan kualitatif dengan proses pengumpulan data menggunakan teknik wawancara, dokumentasi, observasi dan Focus Group Discussion (FGD). Hasil dari penelitian ini terlihat, variasi hasil GUG dalam mendorong internasionalisasi, yaitu: fokus pada reputasi internasional, fokus pada networking internasional, dan fokus pada global branding.

\section{Pendahuluan}

Penyelenggaraan institusi pendidikan saat ini memasuki tantangan baru yang belum terpikirkan sebelumnya. Banyak perubahan yang harus disiapkan oleh institusi pendidikan jika ingin tetap bertahan dari persaingan yang semakin ketat. Perguruan Tinggi (PT) baik Perguruan Tinggi Negeri (PTN), terlebih lagi Perguruan Tinggi Swasta (PTS), termasuk Perguruan Tinggi Muhammadiyah (PTM), harus melakukan perubahan dalam pengelolaan institusinya. Pengelolaan institusi yang baik berbasis Good University Governance

* Corresponding author. Tel.: +62-813-9211-4464; e-mail: mutiarin71 @ gmail.com 
(GUG) akan memberikan dampak positif bagi semua stakeholderl pemangku kepentingan. Saat ini GUG bukan saja untuk mendorong masyarakat dalam negeri untuk mempercayai kredibilitas PTN maupun PTS dan PTM, namun juga untuk menumbuhkan kepercayaan masyarakat internasional. Untuk itu persoalan internasionalisasi program studi menjadi salah satu strategi yang banyak dilakukan oleh Perguruan Tinggi.

Dalam upaya mendorong GUG untuk daya saing PT, pada 17 Agustus 2018, Ristekdikti mengumumkan klasterisasi perguruan tinggi Indonesia Tahun 2018. Hasilnya, ada 14 perguruan tinggi masuk pada klaster 1, 72 perguruan tinggi pada klaster 2, 299 perguruan tinggi pada klaster 3, 1.470 perguruan tinggi pada klaster 4 dan 155 perguruan tinggi masuk pada klaster 5 (Ristekdikti, 2018). Hasil klaster 1-5 dapat dilihat pada gambar 1 dibawah ini:

Klaster Perguruan Tinggi Tahun 2018

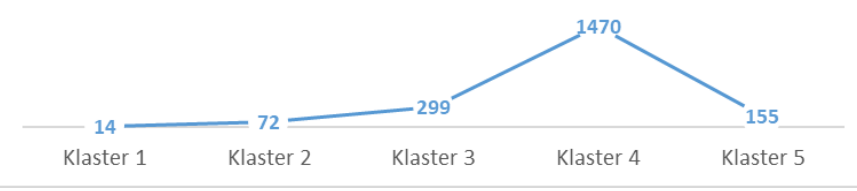

Gambar 1 Klaster Perguruan Tinggi Tahun 2018 Sumber: Ristekdikti, 2017

Berdasarkan gambar 1 tersebut diatas, dapat diketahui bahwa hanya 14 PT yang berada pada klaster 1, sementara 1.470 PT menempati klaster 4 yang merupakan klaster dengan PT terbanyak. Ini menunjukkan kualitas PT di Indonesia masih memerlukan banyak perbaikan. Berdasarkan fakta diatas, maka menjadi penting memahami bagaimana GUG mampu mendorong internasionalisasi prodi sebagai salah satu indikator dari Pemeringkatan Perguruan Tinggi. Data internasionalisasi prodi, salah satunya melalui student mobility dapat dilihat dari Tabel 1 dibawah ini:

Tabel 1 Data Internasionalisasi Prodi Melalui Student Mobility

\begin{tabular}{|l|r|r|}
\hline \multicolumn{1}{|c|}{ Negara } & $\begin{array}{c}\text { Indonesian } \\
\text { outbound students }\end{array}$ & $\begin{array}{c}\text { Overseas } \\
\text { inbound students }\end{array}$ \\
\hline Jepang & 20134 & 486 \\
\hline Australia & 16383 & 292 \\
\hline China & 13000 & 1032 \\
\hline US & 8727 & 93 \\
\hline Malaysia & 7986 & 2753 \\
\hline Singapore & 6695 & 28 \\
\hline Jerman & 5575 & 295 \\
\hline UK & 3239 & 22 \\
\hline Korsel & 1483 & 803 \\
\hline Belanda & 1151 & 326 \\
\hline Filipina & 207 & 115 \\
\hline India & 122 & 57 \\
\hline Thailand & 104 & 1393 \\
\hline
\end{tabular}

\begin{tabular}{|l|l|r|}
\hline \multicolumn{1}{|c|}{ Negara } & \multicolumn{1}{c|}{$\begin{array}{c}\text { Indonesian } \\
\text { outbound students }\end{array}$} & $\begin{array}{c}\text { Overseas } \\
\text { inbound students }\end{array}$ \\
\hline Kamboja & & 169 \\
\hline Perancis & & 287 \\
\hline $\begin{array}{l}\text { Timor } \\
\text { Leste }\end{array}$ & & 4148 \\
\hline Turki & & 72 \\
\hline Vietnam & & 130 \\
\hline
\end{tabular}

Sumber: Ristekdikti, 2018

Berdasarkan Tabel 1 diatas diketahui bahwa Indonesia mengirimkan 84.806 mahasiswa ke luar negeri, sedangkan arus mahasiswa luar negeri/ inbound ke Indonesia baru sejumlah 12.501 mahasiswa atau baru mencapai $14,74 \%$ secara keseluruhan. Ini menjadi catatan tersendiri bila melihat dikaitkan dengan pemeringkatan PT yang secara langsung terkait dengan upaya GUG mendorong internasionalisasi prodi. Oleh karena itu, penelitian ini melihat urgensi pentingnya keterkaitan GUG dalam mendorong internasionalisasi prodi, khususnya pada prodi Ilmu Pemerintahan Universitas Muhammadiyah Yogyakarta (IP-UMY), dan prodi Manajemen dan Kebijakan Publik, Universitas Gadjah Mada (MKP-UGM).

\section{Teori}

\subsection{Good University Governance}

Good University Governance merupakan upaya pengelolaan perguruan tinggi yang dikenalkan di Indonesia seiring dengan prinsip good governance pada tataran pemerintahan oleh UNDP secara luas sejak Tahun 1996. Kemudian Marshall \& Jaggers, 2000; Karatnycky, 2000; Kaufmann, Kraay, \& Zoido-Lobatón, 2002; Howell, 2013; Transparency International, 2019; United Nations Development Programme (UNDP), 1997; menjelaskan indikator subyektif good governance sebagai berikut dalam empat indikator besar yaitu: polity score, civil liberties, political rights, press freedom, voice and accountability, political stability and lack of violence, law and order, rule of law, government effectiveness, corruption perception index, dan Graft.

Prinsip-prinsip atau karakteristik dasar dari good governance masih relevan untuk diterapkan dalam konsep GUG (Abualrub \& Pinheiro, 2017); (Pietrucha, 2017); dan (Shattock, 2006). Dalam penyelenggaraannya, sebuah institusi perguruan tinggi harus memenuhi prinsip-prinsip partisipasi, orientasi pada konsensus, akuntabilitas, transparansi, responsif, efektif dan efisien, equiti (persamaan derajat) dan inklusivitas, dan penegakan/ supremasi hukum. Prinsipprinsip manajerial tersebut diterapkan untuk mendukung fungsi-fungsi dan tujun dasar pendidikan tinggi. Dengan demikian dapat dipahami PT yang menerapkan GUG 
adalah PT yang mengadopsi seluruh atau sebagian prinsip good governance dalam PT yang bersangkutan.

Pada awal tahun 1997, GUG mulai secara luas diterapkan di Indonesia. Dengan GUG, Muktiyanto, (Muktiyanto, 2016), menjelaskan bahwa hubungan GUG dan kinerja Program Studi dipengaruhi oleh penerapan akuntansi manajemen, teknik manajemen dan pilihan prioritas strategi sebagai mediasi fit. Kemudian studi dari Pratolo et al., (2015); menunjukkan bahwa beberapa PTS besar telah menerapkan GUG, sedangkan PTS kecil masih sangat lemah dalam GUG. Studi yang lain dari Khadafi et al., (2018) menunjukkan peran universitas dalam menunjang internasionalisasi ini dianggap perlu untuk dilaksanakan karena isu internasionalisasi merupakan salah satu dampak globalisasi dunia, tidak hanya dalam bidang teknologi informasi tetapi juga dalam bidang pendidikan.

\subsection{Internasionalisasi dalam Pendidikan Tinggi}

Internasionalisasi menjadi trend bagi banyak perguruan tinggi (Hazelkorn, 2015), (Osborne, 2003), (Salter \& Tapper, 2002), (Porsteinsson, 2010). Selanjutnya, Knight dalam Scott (2000) menyatakan strategi internasionalisasi pendidikan tinggi sebagai proses integrasi internasional/ antar dimensi ke dalam pengajaran, penelitian dan pelayanan dari institusi. Davis \& Olsen dalam Scott (2000) mengidentifikasi enam strategi dalam program internasionalisasi: (a) program pelajar internasional; (b) layanan dukungan siswa berskala internasional; (c) penyelenggaraan pendidikan internasional jarak jauh; (d) internasionalisasi pengajar, melalui internasionalisasi dari isi dan bentuk dari kurikulum dan melalui pengalaman internasional; (e) internasional bantuan teknis dan pelatihan; dan (f) internasionalisasi dalam penelitian. Internasionalisasi pendidikan tinggi berimplikasi pada pengejaran image dan kualitas internasional dalam menjadikan intitusi sebagai intitusi yang top dan memiliki kompetisi global.

Internasionalisasi prodi terjadi seiring dengan meluasnya isu masyarakat pengetahuan akan bergeser ke penguasaan dan pengelolaan pengetahuan/ enterprise of knowledge (Shin et al., 2011). Benchmark universitas akan mengalami perubahan dari model USA ke model dunia yang lebih general. Model dunia adalah model agregat yang membandingkan universitas satu dengan yang lain dengan indikator yang sama, misalnya jumlah publikasi dan sitasi, mahasiswa asing dan seterusnya seperti pada gambar 2 .

Ilmu pengetahuan dimasa yang akan datang akan bercorak global yang disebarkan melalui internet dan jurnal internasional. Metode dan norma akademik akan digunakan dalam ruang lingkup global. Selain itu daya saing perguruan tinggi juga dapat dilihat dari perspektif perangkingan nasional maupun global sebagai reputasi global (Knight, 2015). Internasionalisasi perguruan tinggi dan program studi menurut Knight (2015) memiliki lima kecenderungan, yaitu sebagai berikut:

a) Myth one: Foreign students as internationalization agents: "more foreign students on campus will produce more internationalized institutional culture and curriculum";

b) Myth two: International reputation as a proxy for quality: "the more international a university is the better its reputation";

c) Myth three: International institutional agreements: "the greater number of international agreements or network memberships a university has the more prestigious and attractive it is",

d) Myth four: International accreditation: "the more international accreditation stars an institution has, the more internationalized it is and ergo the better it is"; dan

e) Myth five: Global branding: "an international marketing scheme is the equivalent of an internationalization plan".

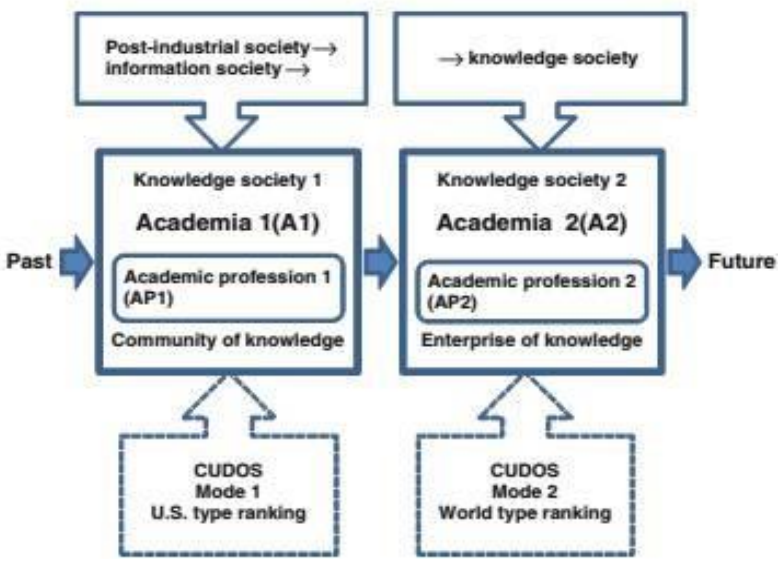

Gambar 2 Knowledge Society and University Rangking Sumber: Shin et al., 2011

Perangkingan merupakan 'calculative technology' par excellence; yang menyusun liga universitas secara tangible dan intangible. Menurut Morphew dan Swansons (dalam Shin \& Harman, 2009): "Rankings are the Swiss knife of higher education - they are a single tool with many uses". Dengan kata lain rangking adalah massifikasi, marketisasi, dan globalization pendidikan tinggi seperti dalam gambar 3 dibawah.

Pada dasarnya ada dua mainstream ideologi yang mempengaruhi perangkingan universitas didunia, yaitu penerapan standarisasi proses pendidikan yang dinamakan dengan egalitarianisme dan elitisme. Ideologi egalitarianisme membentuk quality assurance system (internal quality assurance) yang berlaku diseluruh dunia, misalnya $A U A N$ QA, European $Q A$ dan seterusnya. Ideologi elitisme membentuk sistem perangkingan. Dua ideologi ini secara simultan 
menghasilkan sistem hibrid, yang terdiri dari sistem perangkingan multi-liga seperti QS, Times Higher dan Sianjiongtau, perangkingan yang berbasis pada persepsi pelanggan, sistem perangkingan berbasis regional atau wilayah tertentu dan sistem perangkingan yang berbasis disiplin tertentu. Pada sisi lain, reputasi adalah discourses yang tidak secara langsung dihasilkan dari ranking seperti dihasilkan melalui relasi berbagai aktor pemerintah, civil society, private sector, students, families and alumni, and the broader publics of national and transnational society.

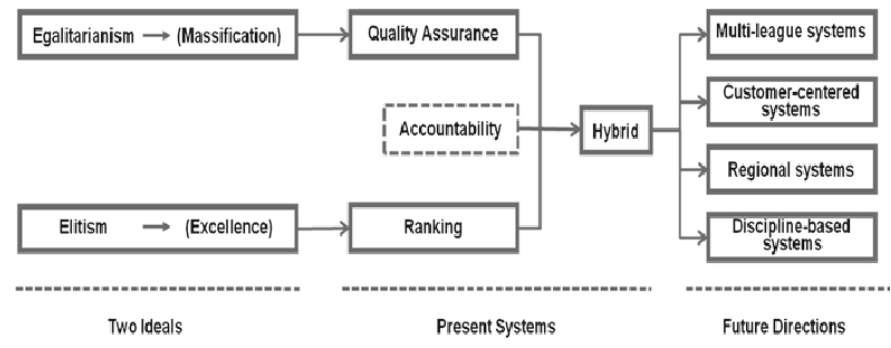

Gambar 3 Masa Depan Sistem Perangkingan Sumber: Shin et al., 2011

\section{Metode Penelitian}

Penelitian ini menggunakan pendekatan kualitatif untuk mendapatkan gambaran tentang good university governance dalam mendorong internasionalisasi prodi. Data penelitian didapat dari sumber utama, yakni Pemangku Kepentingan dari Prodi Ilmu Pemerintahan dan Prodi MKP UGM. Dalam penelitian kualitatif, obyektivikasi data akan didapatkan dengan memberikan kesempatan yang luas kepada obyek untuk bertutur tentang sesuatu. Artinya peneliti tidak memiliki otoritas untuk melakukan treatment, baik mengarahkan agar responden memilih jawaban tertentu ataupun menginterpretasikan makna keluar dari obyek yang diteliti (Creswell, 2012). Pengambilan data dilakukan dengan wawancara, dokumentasi, observasi, dan Focus Group Discussion (FGD).

\section{Hasil Penelitian dan Pembahasan}

\subsection{GUG dan Strategi Internasionalisasi di Prodi IP $U M Y$}

Pemeringkatan maupun survei seperti yang dilakukan oleh QS World University Ranking, Times Higher Education, Webometric, peringkat perguruan tinggi oleh Dikti, dan sebagainya merupakan wujud kualitas PT secara global. Ini menunjukkan lingkungan eksternal yang mengalami perubahan signifikan dan semakin kritis akan mempengaruhi upaya PT termasuk prodi dibawahnya untuk merespon perubahan lingkungan tersebut.
Sebelum melakukan internasionalisasi, terlebih dahulu prodi IP UMY melakukan analisis lingkungan yang diperoleh dengan SWOT sebagai berikut:

Tabel 2 SWOT Internasionalisasi Prodi IP UMY

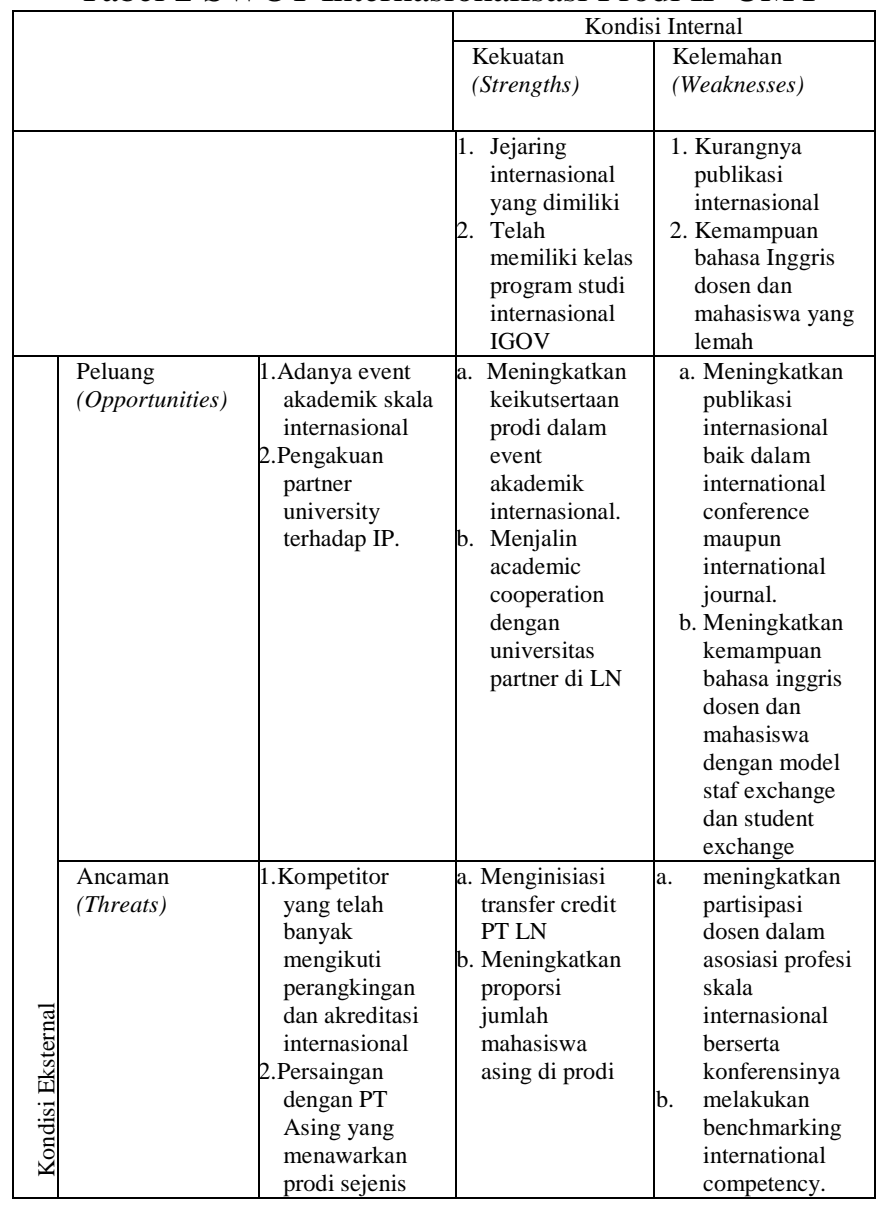

Sumber: Hasil analisis, 2018

Program Studi IP UMY mengalami dinamika yang sangat cepat dan radikal yang salah satunya dipicu oleh perubahan RENSTRA Universitas dari terakreditasi A ditingkat Nasional mengarah pada rencana World Class University (WCU). Dengan adanya perubahan ini diharapkan UMY pada umumnya dan IP UMY pada khususnya dapat mencapai sasaran sebagai Prodi yang memiliki reputasi tinggi tidak hanya di tingkatan Nasional tetapi juga dikawasan Asia Pasifik. Perubahan rencana strategis ini tentunya memberikan konsekuensi manajerial baik ditingkat universitas maupun fakultas dan program studi. Perubahan ini terus menerus memicu setiap prodi yang berada di lingkungan UMY untuk berusaha mengintegrasikan arah organisasi terhadap citacita internasionalisasi.

IP UMY mengikuti road map internasionalisasi prodi yang sudah dicanangkan oleh universitas secara terencana, implementatif dan melakukan evaluasi dari capaian internasionalisasi yang dilakukan. 
Seiring dengan internasionalisasi di UMY, sejak Tahun 2010, Prodi IP UMY telah mendirikan kelas internasional, yaitu International Class of Government (IGOV). Berikut adalah gambaran aspek internasionalisasi pada level universitas, fakultas, dan prodi :

\section{Enam Aspek Internationalisasi di UMY}

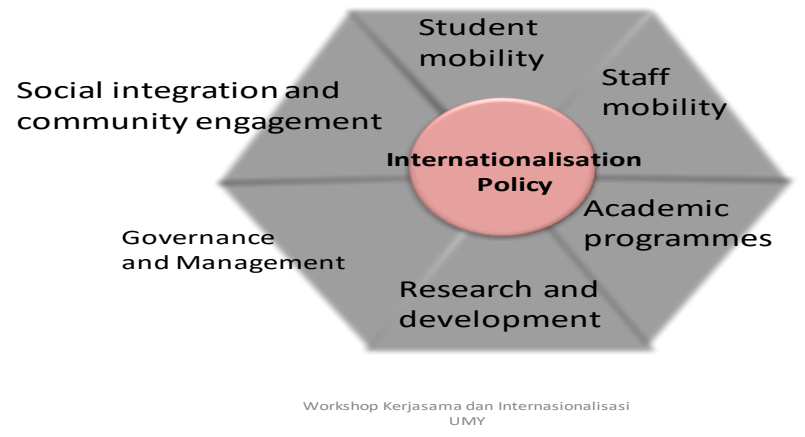

Gambar 4 Enam Aspek Internationalisasi di UMY Sumber: Rosyidi, 2015

Dari gambar 4 tersebut, menunjukkan bahwa UMY sejak Tahun 2015 mendorong internasionalisasi dengan enam program utama. Kemudian untuk targetnya digambarkan pada Gambar 5 dibawah ini:

Gambar 5 Program dan Target Internasionalisasi di UMY

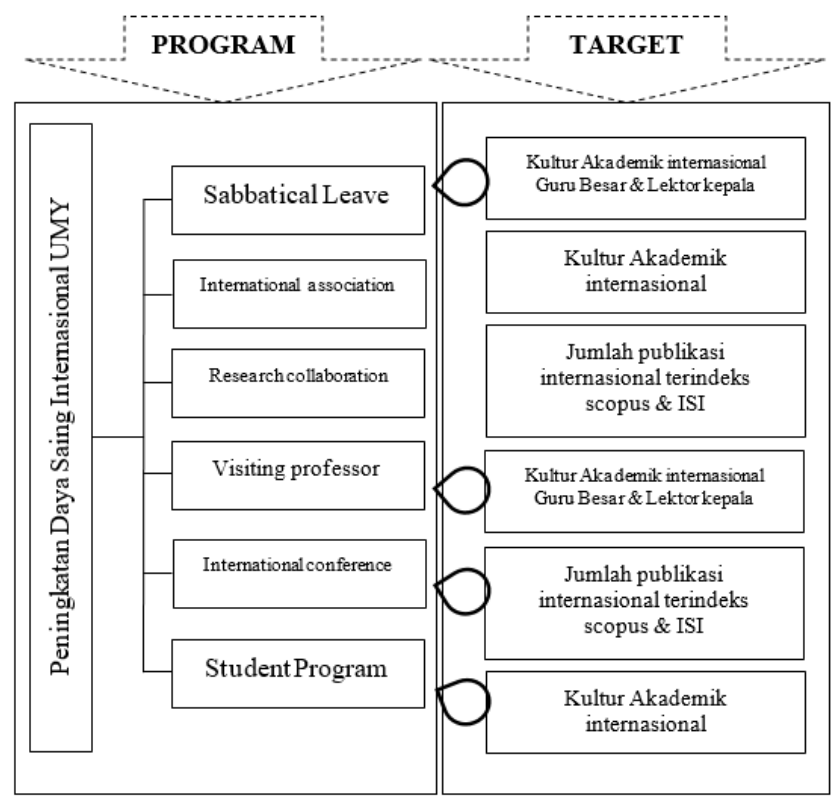

Sumber: Rosyidi, 2015

Untuk itu, UMY dan khususnya IP UMY mengimplementasikannya pada Mou baik dengan PT/ instansi LN dan DN dengan tujuan memperkuat internasionalisasi. Beberapa kegiatan yang dirancang untuk mendukung internasionalisasi adalah sebagai berikut dalam Tabel 3:
Tabel 3 PT/ Instansi yang Menjalin Kerjasama

\begin{tabular}{|c|c|c|c|c|c|}
\hline \multirow[t]{2}{*}{ No } & \multirow[b]{2}{*}{$\begin{array}{l}\text { PT LN/ } \\
\text { Instansi }\end{array}$} & \multirow{2}{*}{$\begin{array}{c}\text { Jumlah } \\
\text { MOU } \\
\& \\
\text { MOA } \\
\end{array}$} & & \multirow[b]{2}{*}{ Kegiatan } & \multirow{2}{*}{$\begin{array}{c}\text { Manfaat yg } \\
\text { Telah } \\
\text { Diperoleh }\end{array}$} \\
\hline & & & $\begin{array}{l}\text { Kurun } \\
\text { waktu }\end{array}$ & & \\
\hline 1. & $\begin{array}{l}\text { Luar } \\
\text { Negeri/ } \\
\text { LN }\end{array}$ & $\begin{array}{l}145 \\
\text { MOU } \\
42 \\
\text { MOA }\end{array}$ & $\begin{array}{l}\text { antara } \\
2015- \\
2025\end{array}$ & 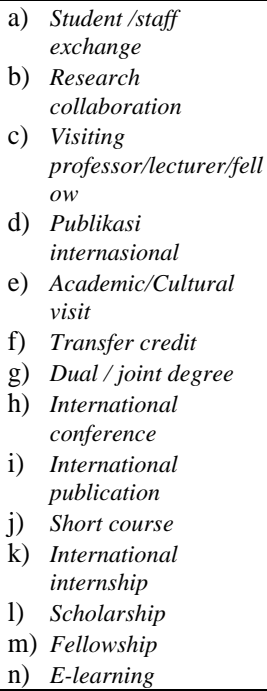 & $\begin{array}{l}\text { Meningkatkan } \\
\text { perangkingan } \\
\text { dan akreditasi } \\
\text { internasional }\end{array}$ \\
\hline 2. & $\begin{array}{l}\text { Dalam } \\
\text { Negeri/ } \\
\text { DN }\end{array}$ & $\begin{array}{l}120 \\
\text { MOU } \\
58 \\
\text { MOA }\end{array}$ & $\begin{array}{l}\text { antara } \\
2015- \\
2025\end{array}$ & $\begin{array}{ll}\text { a) } & \text { Magang } \\
\text { b) } & \text { Seminar /Konferensi } \\
\text { c) Nasional } \\
\text { d) Workshop } \\
\text { e) Publikasi } \\
\text { jurnal/buku/ } \\
\text { monograph } \\
\text { f) Dosen Tamu } \\
\text { g) Pakar } \\
\text { h) Kerjasama industri } \\
\text { i) } & \text { Rekrutment pegawai } \\
\text { j) } & \text { internship }\end{array}$ & $\begin{array}{l}\text { Meningkatkan } \\
\text { akreditasi } \\
\text { nasional dan } \\
\text { global } \\
\text { benchmark }\end{array}$ \\
\hline
\end{tabular}

Sumber : LKS UMY, 2018

Berdasarkan Tabel 3 tersebut dapat dilihat variasi kegiatan kerjasama antara dengan PT maupun industri maupun institusi dalam negeri maupun luar negeri memiliki implikasi yang berbeda.

Kerjasama LN lebih banyak ditujukan untuk meningkatkan perangkingan dan akreditasi internasional, sedangkan kerjasama DN berimplikasi pada meningkatkan akreditasi nasional dan global benchmark.

Pengelolaan internasionalisasi dilakukan oleh Lembaga Kerjasama/ LKS UMY. Berikut adalah area kerjasama dalam bidang dalam gambar 6 :

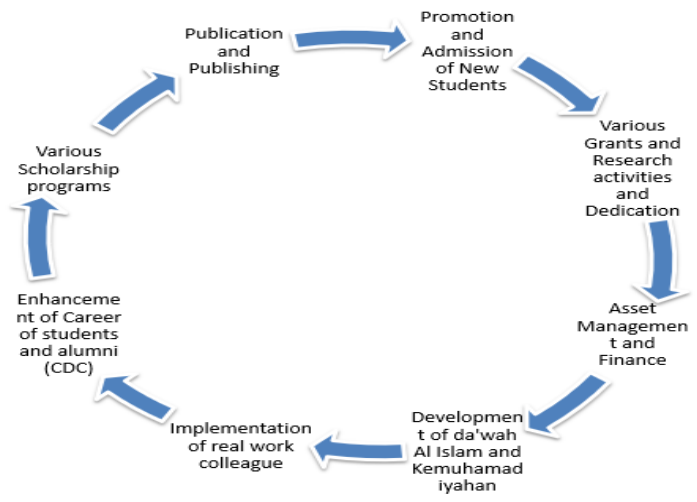

Gambar 6 Desain aktivitas internasionalisasi oleh LKS UMY

Sumber: LKS UMY, 2018 
Siklus kegiatan yang dirancang oleh LKS UMY ini dimulai dari tahap promosi, kemudian memberikan hibah secara kompetitif, keuangan dan aset dikelola profesional, melakukan dakwah dan mendorong terealisirnya MoU dan MoA, kemudian ada pengembangan diri mahasiswa melalui Career Development Center, pemberian beasiswa secara kompetitif, serta mendorong output publikasi secara internasional.

Pada Tahun 2018, IP UMY mengikuti langkah UMY melaksanakan dukungan untuk program internasionalisasi sebagai berikut:

Tabel 4 Dukungan untuk Program Internasionalisasi

\begin{tabular}{|c|c|}
\hline Program & Dukungan \\
\hline $\begin{array}{l}\text { Internasio- } \\
\text { nalisasi }\end{array}$ & $\begin{array}{l}\text { a) Anggaran untuk internasionalisasi } \\
\text { kurikulum dan SDM Prodi } \\
\text { Internasional } \\
\text { b) Anggaran untuk dosen dan pakar } \\
\text { tamu LN } \\
\text { c) Fasilitas guest house yang memadai } \\
\text { d) Penawaran, sistem aplikasi dan } \\
\text { manajemen mahasiswa internasional } \\
\text { yang jelas } \\
\text { e) Fasilitas dan dukungan bagi } \\
\text { mahasiswa internasional } \\
\text { f) Anggaran untuk penyelenggaran } \\
\text { pertukaran mahasiswa/ dosen } \\
\text { g) Anggaran untuk pengalaman } \\
\text { internasional mahasiswa dan staf } \\
\text { akademik/ non akademik } \\
\text { h) Kantor Internasional yang dikelola } \\
\text { secara profesional } \\
\text { Lembaga bahasa dengan program } \\
\text { yang efektif }\end{array}$ \\
\hline Program & Dukungan \\
\hline $\begin{array}{l}\text { Website } \\
\text { dan ICT }\end{array}$ & $\begin{array}{l}\text { a) WEB bilingual yang dirancang dan } \\
\text { dikelola oleh tenaga profesional } \\
\text { b) WEB yang memiliki size yang } \\
\text { memadai, menyapa kebutuhan } \\
\text { publik internasional yang luas } \\
\text { (visibility), mempublikasikan } \\
\text { c) dokumen-dokumen dalam rich files } \\
\text { dan tulisan ilmiah para scholars } \\
\text { d) ICT yang efektif untuk kebutuhan } \\
\text { pembelajaran (E-learning) } \\
\text { e) ICT yang efektif untuk kebutuhan } \\
\text { manajemen } \\
\text { f) ICT yang efektif untuk pengelolaan } \\
\text { perpustakaan }\end{array}$ \\
\hline $\begin{array}{l}\text { SDM yang } \\
\text { berkualitas } \\
\text { internasional }\end{array}$ & $\begin{array}{l}\text { a) Beasiswa studi lanjut ke universitas } \\
\text { berreputasi intl. (kompetitif) } \\
\text { b) Beasiswa riset pos-doktoral dan } \\
\text { sabbatical leave bagi doktor dan } \\
\text { profesor (kompetitif) } \\
\text { c) Beasiswa magang staf di lembaga } \\
\text { bereputasi internasional. }\end{array}$ \\
\hline
\end{tabular}

\begin{tabular}{|l|l|}
\hline Program & \multicolumn{1}{|c|}{ Dukungan } \\
\hline & d) $\begin{array}{l}\text { (kompetitif) } \\
\text { Beasiswa pelatihan peningkatan } \\
\text { kualitas SDM bagi dosen dan staf } \\
\text { administrasi }\end{array}$ \\
& e) $\begin{array}{l}\text { Penghargaan (award) bagi peneliti/ } \\
\text { dosen berprestasi unggul }\end{array}$ \\
\hline
\end{tabular}

Sumber: Budiyanto, 2018

Sejak melaksanakan program internasionalisasi tersebut, mahasiswa, dosen, dan karyawan UMY termotivasi untuk sejajar dengan PT lain di Indonesia maupun diluar negeri. Networking untuk memperluas riset kolaborasi, meningkatkan publikasi internasional, menempatkan para dosen sebagai visiting lecturer, guest lecturer, maupun visiting professor terus dilakukan. Dari sisi mahasiswa, dilakukan student exchange, transfer credit, dan juga international conference yang digiatkan untuk meningkatkan rangking student mobility.

Berdasarkan hasil internasionalisasi sejak Tahun 2015 yang lalu beberapa hasil yang telah dicapai pada Tahun 2018 adalah sebagai berikut pada Tabel 5:

Tabel 5 Capaian internasionalisasi UMY 2016-2018

\begin{tabular}{|c|c|c|}
\hline Indikator & $\begin{array}{l}\text { Capaian } \\
2016 / 2017\end{array}$ & $\begin{array}{c}\text { Target } \\
2017 / 2018 \\
\end{array}$ \\
\hline $\begin{array}{l}\text { Persentase jumlah prodi } \\
\text { terakreditasi A }\end{array}$ & $54 \%$ & $54 \%$ \\
\hline $\begin{array}{l}\text { Persentase jumlah prodi } \\
\text { tersertifikasi } A U N-Q A\end{array}$ & - & - \\
\hline $\begin{array}{l}\text { QS Stars kategori facilities, } \\
\text { social responsibilities \& } \\
\text { inclusiveness }\end{array}$ & 5 & 5 \\
\hline QS Stars kategori teaching & 4 & 4 \\
\hline QS Stars kategori employability & 3 & 3 \\
\hline $\begin{array}{l}\text { QS Stars kategori } \\
\text { internationalization }\end{array}$ & 2 & 3 \\
\hline QS Stars kategori research & 0 & 1 \\
\hline $\begin{array}{l}\text { Persentase kegiatan akademik/ } \\
\text { non-akademik yang } \\
\text { menggunakan sistem informasi } \\
\text { terintegrasi }\end{array}$ & $50 \%$ & $60 \%$ \\
\hline $\begin{array}{l}\text { Persentase unit kerja yang } \\
\text { menggunakan sistem eksekutif } \\
\text { pendukung keputusan }\end{array}$ & $5 \%$ & $10 \%$ \\
\hline Rangking pada $4 I C U$ & 29 & 25 \\
\hline Rangking pada Webometrics & 19 & 15 \\
\hline $\begin{array}{l}\text { Jumlah kerjasama yang } \\
\text { menghasilkan publikasi } \\
\text { SCOPUS }\end{array}$ & $5 \%$ & $10 \%$ \\
\hline $\begin{array}{l}\text { Persentase jumlah international } \\
\text { staffs }\end{array}$ & $11.3 \%$ & $12 \%$ \\
\hline $\begin{array}{l}\text { Persentase jumlah international } \\
\text { students }\end{array}$ & $2.19 \%$ & $3 \%$ \\
\hline $\begin{array}{l}\text { Persentase jumlah inbound } \\
\text { exchange students }\end{array}$ & $0.88 \%$ & $1 \%$ \\
\hline $\begin{array}{l}\text { Persentase jumlah outbound } \\
\text { exchange students }\end{array}$ & $0.56 \%$ & $0.8 \%$ \\
\hline
\end{tabular}

Sumber: Universitas Muhammamdiyah Yogyakarta, 2018

Oleh karena itu Prodi IP mendukung internasionalisasi prodi. Grand strategy 
internasionalisasi prodi IP dirumuskan lebih dalam dan direncanakan dengan matang. Kinerja dari IP UMY telah memenuhi standar nasional, sehingga hal tersebut menjadi salah satu langkah awal grand strategy menuju Akreditasi Internasional yang lebih baik lagi bagi IP UMY.

\subsection{GUG dan Strategi Internasionalisasi di Prodi MKP $U G M$}

Deskripsi program MKP UGM menjelaskan bahwa Program Studi S1 (Prodi S1) Jurusan Manajemen dan Kebijakan Publik (MKP) berdiri sejak Tahun 1957 dengan nama Jurusan Ilmu Administrasi Negara (JIAN). JMKP merupakan lembaga pendidikan administrasi publik tertua di Indonesia. Sejak Tahun 2010, JIAN berubah nama menjadi JMKP sebagai konsekuensi dinamika perkembangan Ilmu Administrasi Negara, serta untuk memperluas ruang gerak alumni. JMKP sesuai dengan nilai kejuangannya, strengthening public governance, secara khusus hadir dengan komitmen berkelanjutan untuk memperkuat tata kelola sektor publik yang demokratis melalui jalur pendidikan, penelitian dan pengabdian pada masyarakat.

Prodi MKP UGM juga telah memiliki kelas internasional dengan nama Program Sarjana Internasional dalam Kebijakan Publik dan Manajemen (IUP di PPM). IUP merupakan program kuliah berbahasa Inggris yang dirancang untuk merespon tantangan baru baik di tingkat lokal maupun nasional maupun global. Program Sarjana Internasional dalam Kebijakan Publik dan Manajemen (IUP PPM) adalah program pengelolaan kebijakan publik pertama di Indonesia yang telah diakreditasi oleh $A U N$ (Jaringan Universitas ASEAN) pada tingkat program dibawah payung ASEAN-QA. Pengelolaan IUP UGM tidak tersentralisasi ditingkat universitas, melainkan kewenangan dibawah prodi dan atau fakultas yang menyelenggarakan program tersebut. Sebelum IUP di PPM didirikan, UGM telah memiliki delapan prodi IUP yaitu Prodi Akuntansi, Prodi Bisnis, Prodi Ekonomi, Prodi Hukum, Prodi Hubungan Internasional, Prodi Pendidikan Dokter, Prodi Ilmu Komputer dan Prodi Ilmu Kimia. Dalam perjalannnya, ada dua prodi yang telah ditutup, yaitu IUP Prodi Sastra Inggris dan Prodi Pariwisata.

Dari sisi standar mutu, Prodi S1 MKP terakreditasi A oleh Badan Akreditasi Nasional-Perguruan Tinggi (BAN-PT) Departemen Pendidikan dan Kebudayaan RI. Dilevel internasional, prodi S1 MKP merupakan prodi S1 Administrasi Publik pertama yang terakreditasi ASEAN University Network Quality Assurance (AUNQA) pada Tahun 2014. Proses akreditasi AUN QA dilakukan oleh AUN bekerjasama dengan German Academic Exchange Service (DAAD) dan University of Potsdam.
IUP di PPM mengelola mahasiswa dengan aktivitas, yaitu sebagai berikut:

a) Study Abroad Program, yaitu pertukaran pelajar pada Program Studi Luar Negeri (satu sampai dua semester di universitas mitra);

b) Student exchange or credit transfer/ Transfer siswa atau transfer kredit (satu sampai dua semester di universitas mitra);

c) Internship/ Magang (tiga sampai enam bulan di organisasi internasional yang berbasis di Indonesia, kedutaan besar, badan pemerintah yang terkait secara internasional, lembaga donor, LSM internasional, atau perusahaan multinasional); dan

d) International executive training or short course program/ pelatihan eksekutif internasional atau program kursus singkat dalam (satu minggu sampai tiga bulan diluar negeri).

Mitra PT LN IUP MKP adalah:

a) University of Agder, Norwegia;

b) University of Groningen, Netherland;

c) University of Leeds, United Kingdom;

d) The University of Melbourne, Australia;

e) University of Birmingham, United Kingdom;

f) Queen Mary University of London, United Kingdom;

g) Utrecth University, Netherland;

h) Leiden University, Netherland;

i) Sungkyunkwan University, South Korea; dan

j) De La Salle College of St. Benilde, Philiphines.

Kegiatan IUP MKP ini juga mendapat dukungan dari Global Enggagement Office Fisipol UGM dan Kantor Urusan Internasional UGM/ Office of International Affairs (OIA). Desain kegiatan yang dilakukan OIA UGM adalah:

a) Mengelola dan mengembangkan kerja sama internasional dengan mitra asing. Universitas dan lembaga internasional;

b) Menginisiasi dan melaksanakan $\mathrm{MoU}$ dengan universitas atau lembaga mitra di luar negeri;

c) Mengorganisir Program Budaya dan Pendidikan untuk siswa internasional;

d) Mendukung berbagai konferensi internasional dan kegiatan yang diadakan di Universitas Gadjah Mada; dan

e) Memberikan bantuan, saran, dan informasi bagi siswa LN yang akan tinggal di Yogyakarta, Indonesia untuk belajar, mengajar, dan melakukan penelitian di Universitas Gadjah Mada; bantuan visa dan izin lainnya yang penting.

Dalam internasionalisasi, MKP UGM selain mendirikan kelas IUP di MKP juga terus melaksanakan strategi internasionalisasi pada level Jurusan maupun Prodi. Berikut adalah kerangka internasionalisasi di MKP UGM: 


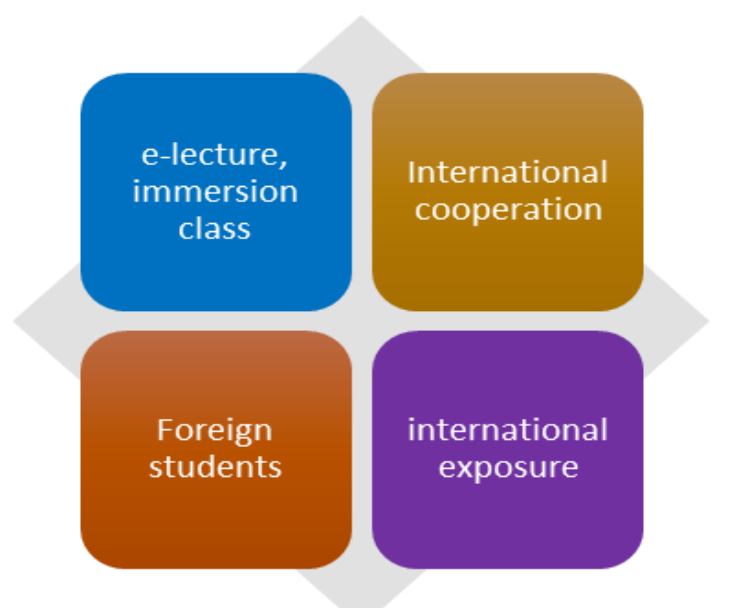

Gambar 7 Internasionalisasi Prodi MKP UGM Sumber: Fisipol UGM, 2017

Prodi MKP juga menyadari bahwa mengelola hubungan dengan calon mahasiswa, mahasiswa, alumni, sumberdaya anggaran, menekan belanja, dan meningkatkan kapasitas pendapatan menjadi sangat penting diera internasionalisasi saat ini. Lengkapnya fasilitas infrastruktur fisik dan kelembagaan yang dimiliki MKP UGM menjadi faktor penting dibalik keberhasilan jurusan ini mengembangan diri menjadi prodi yang mendukung UGM masuk dalam jaringan internasional pada semua jenis perangkingan internasional seperti ARWU (Academic Ranking World University), THES (the Times Higher Education Supplement), Webometric, 4ICU(4 International Colleges and University), Top 100 Asia, QS World University Rangking.

Sebagai bagian dari program internasionalisasi, prodi MKP UGM menyelenggarakan kelas e-lecture berbahasa Inggris yang dilakukan bersama Sunkyunkwan University di Korea Selatan. Mata kuliah e-lecture yang diajarkan antara lain comparative local governance, e-governance, dan human reseource management. Selain itu, ditawarkan kelas immersion yang diajarkan sepenuhnya dengan bahasa Inggris seperti corruption and anti corruption dan international institution. Kerjasama luar negeri juga dilakukan dengan mitra PT LN yang telah memiliki MoU bersama.

Dalam dokumen OAI UGM, dijelaskan bahwa Rencana Strategis Kementerian Riset, Teknologi, dan Pendidikan Tinggi (Kemenristekdikti) Tahun 2015-2019; telah mengamanatkan beberapa Perguruan Tinggi Negeri mampu meningkatkan daya saing nasional melalui pencapaian 500 top dunia yang pemeringkatannya dilakukan oleh QS (Quacquarelli Symonds) melalui QS World University Ranking (QS-WUR). Pemeringkatan Perguruan Tinggi secara internasional merupakan salah satu bentuk pengakuan dunia internasional atas kualitas penyelenggaraan Tri Dharma Perguruan Tinggi. Dampak dari pengakuan internasional adalah peningkatan reputasi dan peran Perguruan Tinggi dalam pengembangan IPTEKS. Pencapaian QS-WUR 500 top dunia dihitung melalui skor sesuai kriteria dalam QS World Ranking yaitu academic reputation; employer reputation; faculty/ student ratio; paper per faculty; research and publication; dan internationalization.

Namun dalam perjalanannya, pada Tahun 20132015 dalam QS-WUR, UGM mengalami penurunan peringkat hingga keluar dari 500 besar dunia pada pemeringkatan Tahun 2013 hinggal 2015. Kemudian UGM melakukan perbaikan-perbaikan agar dapat kembali masuk ke dalam 500 besar dunia. Pada tahun 2015, UGM membentuk tim khusus untuk menangani pemeringkatan dan telah melakukan berbagai program. Untuk Tahun 2016, tantangan UGM adalah meneruskan kemajuan pencapaian pada Tahun 2015 demi kesinambungan program peningkatan kualitas. Tahun 2017, UGM masuk kembali ke 500 besar dunia.

Tabel 6 PT/ Instansi yang Menjalin Kerjasama dengan UGM

\begin{tabular}{|c|c|c|c|c|c|}
\hline \multirow[b]{2}{*}{ No. } & \multirow[b]{2}{*}{$\begin{array}{l}\text { PT LN/ } \\
\text { Instansi }\end{array}$} & \multirow[b]{2}{*}{$\begin{array}{l}\text { Jumlah } \\
\text { MOU \& } \\
\text { MOA }\end{array}$} & & \multirow[b]{2}{*}{$\begin{array}{c}\text { Manfaat } \\
\text { Yang Telah } \\
\text { Diperoleh }\end{array}$} \\
\hline & & & $\begin{array}{l}\text { Kurun } \\
\text { waktu }\end{array}$ & Kegiatan & \\
\hline 1 & PT LN & $\begin{array}{l}\text { Australia } \\
- \text { New } \\
\text { Zealand } \\
-25 \\
\text { MOU } \\
\text { Europe - } \\
\text { Middle } \\
\text { East - 49 } \\
\text { MOU } \\
\text { East Asia } \\
\text { - South } \\
\text { Asia - 50 } \\
\text { MOU } \\
\text { Southeast } \\
\text { Asia- } 14 \\
\text { MOU } \\
\text { America } \\
\text { - Africa } \\
\text { - 11 } \\
\text { MOU }\end{array}$ & $\begin{array}{l}\text { antara } \\
2015- \\
2023\end{array}$ & $\begin{array}{l}\text { 1. Consortium } \\
\text { 2. Inter Institutional } \\
\text { Agreements } \\
\text { 3. Research and/ or } \\
\text { Community } \\
\text { Development } \\
\text { Training and } \\
\text { Workshops } \\
\text { 5. Technical } \\
\text { Assistance } \\
\text { Capacity } \\
\text { Building } \\
\text { 7. joint initiatives } \\
\text { (trainings, } \\
\text { workshops, } \\
\text { seminars, paper } \\
\text { publications) } \\
\text { 8. International } \\
\text { Students Summer } \\
\text { Program } \\
\text { 9. Scholarship } \\
\text { 10. Student/staff } \\
\text { exchange } \\
\text { 11. Research } \\
\text { collaboration } \\
\text { 12. Visiting } \\
\text { professor/lecture } \\
\text { r/fellow } \\
\text { 13.Publikasi } \\
\text { internasional } \\
\text { 14. } \\
\text { /Cultural visit } \\
\text { 15. Transfer credit } \\
\text { 16. Dual/joint } \\
\text { degree } \\
\text { 17. International } \\
\text { conference } \\
\text { 18. International } \\
\text { publication } \\
\text { 20. International } \\
\text { internship }\end{array}$ & $\begin{array}{l}\text { Meningkatkan } \\
\text { perangkingan/ } \\
\text { reputasi } \\
\text { internasional, } \\
\text { akreditasi } \\
\text { internasional } \\
\text { memperluas } \\
\text { networking } \\
\text { dan global } \\
\text { branding. }\end{array}$ \\
\hline
\end{tabular}

Sumber: Hasil analisis, 2018 
Berdasarkan sisi kelembagaan, internasionalisasi di MKP UGM menginduk pada strategi UGM dalam upaya meningkatkan perangkingan/ reputasi internasional, akreditasi internasional, memperluas networking dan global branding. Hal ini dilakukan untuk mengejar posisi masuk dalam World Class University.

Berikut adalah tiga strategi WCU UGM yang dapat dilihat pada gambar 8 , yaitu sebagai berikut:

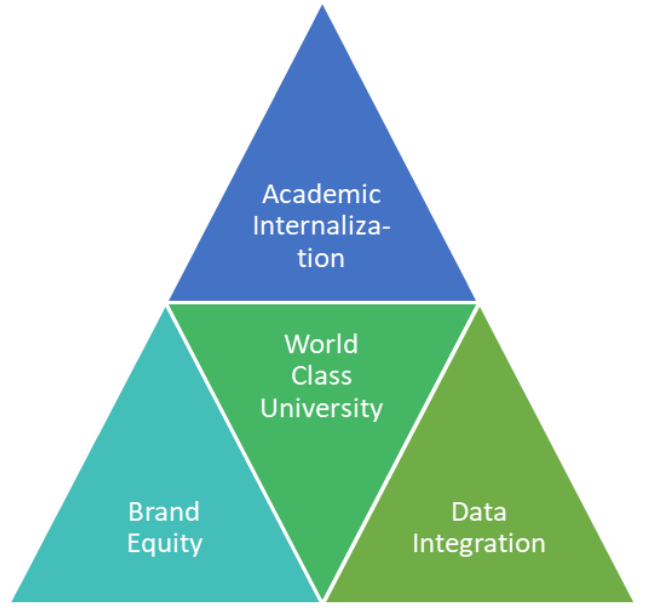

Gambar 8 Strategi UGM mencapai WCU

Sumber: Hasil analisis, 2018 berikut:

Adapun penjelasan gambar 8 diatas, adalah sebagai

\section{Tabel 7 Uraian Penjelasan Strategi UGM} Mencapai WCU

\begin{tabular}{|c|c|}
\hline Strategi & Program \\
\hline $\begin{array}{l}\text { Academic } \\
\text { Internationalization }\end{array}$ & $\begin{array}{l}\text { - Inovasi Summer Course untuk } \\
\text { bidang unggul lintas disiplin } \\
\text { - Program International Visiting } \\
\text { Scholars } \\
\text { - Penguatan dan insentif publikasi } \\
\text { dengan impact factor tinggi dan } \\
\text { atau sitasi tinggi } \\
\text { - Pendampingan proses editing } \\
\text { seminar internasional terindeks } \\
\text { Scopus }\end{array}$ \\
\hline Brand Equity & $\begin{array}{l}\text { - Pendampingan dan penguatan } \\
\text { - } \text { laman (website) lembaga dan unit } \\
\text { - } \text { Standardisasi dan pembuatan } \\
\text { - Keterlibatan dalam Qu Exomosi UGM } \\
\text { - Promosi pendidikan internasional } \\
\text { - Pertemuan alumni internasional } \\
\text { - Malam sahabat UGM } \\
\text { - Penerbitan newsletter } \\
\text { - Keterlibatan dalam program- } \\
\text { program QS }\end{array}$ \\
\hline Data Integration & $\begin{array}{l}\text { - Pembuatan basis data keahlian } \\
\text { - Pengembangan basis data informasi } \\
\text { dosen }(\mathrm{CV}) \\
\text { - Perbaikan data }\end{array}$ \\
\hline
\end{tabular}

Sumber: Hasil analisis, 2018
Dengan berpijak pada perbandingan strategi antara IP UMY dan MKP UGM dapat dijelaskan pola GUG dalam mendorong internasionalisasi prodi sebagai berikut:

Tabel 8 Pola GUG dalam

Mendorong Internasionalisasi Prodi

\begin{tabular}{|c|c|c|}
\hline Prinsip GUG & IP UMY & MKP UGM \\
\hline Partisipasi & $\begin{array}{l}\text { a) Pelibatan dalam } \\
\text { aktivitas } \\
\text { internasionalisasi } \\
\text { secara distributive } \\
\text { kompetitive. } \\
\text { b) Area aktivitas } \\
\text { internasionalisasi } \\
\text { pada wilayah Asia } \\
\text { Pasifik. }\end{array}$ & $\begin{array}{l}\text { a) Pelibatan dalam } \\
\text { aktivitas } \\
\text { internasionalisasi } \\
\text { secara kompetitif } \\
\text { b) Lebih diarahkan } \\
\text { pada aktivitas } \\
\text { internasionalisasi } \\
\text { yang melibatkan } \\
\text { mitra dari Eropa, } \\
\text { Amerika Serikat, } \\
\text { Australia }\end{array}$ \\
\hline $\begin{array}{l}\text { Penegakkan } \\
\text { Hukum }\end{array}$ & $\begin{array}{l}\text { a) Ada reward dan } \\
\text { punishment berdasar } \\
\text { output kegiatan } \\
\text { internasionalisasi }\end{array}$ & $\begin{array}{l}\text { a) Monitoring dan } \\
\text { evaluasi program } \\
\text { internasionalisasi } \\
\text { dilakukan secara } \\
\text { rutin berkala } \\
\text { b) Ada reward dan } \\
\text { punishment }\end{array}$ \\
\hline Transparansi & $\begin{array}{l}\text { a) Rapat perencanaan } \\
\text { internasionalisasi } \\
\text { berbasis Indeks } \\
\text { Kinerja Strategis } \\
\text { (IKS) } \\
\text { b) Pembuatan keputusan } \\
\text { bersifat top down } \\
\text { sesuai roadmap } \\
\text { internasionalisasi }\end{array}$ & $\begin{array}{l}\text { a) Rapat perencanaan } \\
\text { internasionalisasi } \\
\text { sesuai Rencana } \\
\text { Kerja Anggaran } \\
\text { yang direncanakan } \\
\text { RKA } \\
\text { b) Pembuatan } \\
\text { keputusan dengan } \\
\text { hybrid model } \\
\text { tersentralisasi dan } \\
\text { juga desentralisasi } \\
\text { sesuai roadmap } \\
\text { internasionalisasi }\end{array}$ \\
\hline Responsivitas & $\begin{array}{l}\text { Bertanggung jawab } \\
\text { pada Rektor, } \\
\text { Manajemen Fakultas } \\
\text { dan prodi serta } \\
\text { pengelola } \\
\text { internasionalisasi }\end{array}$ & $\begin{array}{l}\text { Bertanggung jawab } \\
\text { pada Manajemen } \\
\text { Fakultas dan prodi } \\
\text { serta pengelola } \\
\text { internasionalisasi }\end{array}$ \\
\hline $\begin{array}{l}\text { Orientasi pada } \\
\text { Konsensus }\end{array}$ & $\begin{array}{l}\text { Menekankan pada } \\
\text { komitmen terhadap } \\
\text { output melalui kontrak } \\
\text { program } \\
\text { internasionalisasi }\end{array}$ & $\begin{array}{l}\text { a) Komitmen dimulai } \\
\text { dari perencanaan } \\
\text { sampai evaluasi } \\
\text { program. } \\
\text { b) Melakukan sharing } \\
\text { commitment } \\
\text { dengan para } \\
\text { pelaksana program } \\
\text { intrernasionalisasi. }\end{array}$ \\
\hline $\begin{array}{l}\text { Efektivitas dan } \\
\text { efisiensi }\end{array}$ & $\begin{array}{l}\text { a) Menggunakan } \\
\text { pengukuran } \\
\text { pencapaian target } \\
\text { IKS } \\
\text { b) Penganggaran sesuai } \\
\text { pagu program }\end{array}$ & $\begin{array}{l}\text { a) Melakukan self } \\
\text { assessment. } \\
\text { b) Memenuhi RKA }\end{array}$ \\
\hline
\end{tabular}




\begin{tabular}{|l|l|l|}
\hline Prinsip GUG & \multicolumn{1}{|c|}{ IP UMY } & MKP UGM \\
\hline & internasionalisasi & \\
& & \\
\hline Akuntabilitas & c) Akuntabilitas internal & a) Akuntabilitas \\
& dan eksternal & internal dan \\
& d) Dana berasal dari & eksternal \\
& dana masyarakat dan & b) Dana berasal dari \\
& mitra kerjasama & APBN dan mitra \\
& & kerjasama \\
\hline
\end{tabular}

Sumber: Hasil analisis, 2018

\section{Kesimpulan}

Penelitian ini mendapatkan kesimpulan dari dua prodi yang diteliti, antara lain sebagai berikut:

a) MKP UGM telah menjalankan program internasionalisasi terlebih dahulu daripada IP UMY yaitu dengan akreditasi AUN QA yang didapat dan menjalankan roadmap internasionalisasi;

b) IP UMY menjalankan internasionalisasi sejak 2015, namun hasilnya telah mampu membawa IP UMY menapak sebagai PT yang mengedepankan internasionalisasi;

c) MKP UMY menjalankan strategi mix antara focus on international reputation, focus on international networking, and focus on global branding. IP UMY menjalankan strategi focus on international reputation, dan focus on international networking; dan

d) GUG yang diimplementasikan secara keseluruhan, mampu mendorong internasionalisasi prodi.

\section{Daftar Pustaka}

Abualrub, I., \& Pinheiro, R. (2017). Global aspirations and local alignments:Investigating university strategies and roles. Tersedia pada https://www.ippapublicpolicy.org//file/paper/5941 7805dcab9.pdf [Diakses pada 20 April 2018].

Budiyanto, G. (2018). Paparan Rektor UMY. Workshop Internasionalisasi UMY Tanggal 12 Agustus 2018, UMY, Yogayakarta.

Creswell, J.W. (2012). Research Design: Pendekatan kualitatif, Kuantitatif dan Mixed; Cetakan ke-2. Yogyakarta: Pustaka Pelajar.

Fisipol (Fakultas Ilmu Sosial \& Ilmu Politik) UGM. (2017). Laporan Kinerja Dekanat Fisipol Periode 2012-2016. Fisipol UGM: Yogyakarta.

Hazelkorn, E. (2015). Rankings and the Reshaping of Higher Education: The Battle for World-Class Excellence. Palgrave Macmillan, UK.

Howell, Llewellyn D. (2013). The handbook of country and political risk analysis. East Syracuse, NY: PRS Group.

Karatnycky, Adrian. (2000). Freedom in the World 2000. Tersedia https://freedomhouse.org/report/freedomworld/freedom-world-2000 [Diakses pada 30 April 2018].

Kaufmann, Daniel., Kraay, Aart., \& Zoido-Lobaton, Pablo. (2002). Governance Matters II: Updated Indicators for 2000/01. Policy Research Working Paper, The World Bank, Washington DC.

Khadafi, M., Haryono, B. S., \& Wanto, A. H. (2018). Evaluasi Kebijakan Internasionalisasi Universitas Brawijaya Dalam Rangka Menuju World Class University. Jurnal Ilmiah Administrasi Publik, Vol. 4(2), pp. 89-99.

Knight, J. (2015). Five Myths about Internationalization. International Higher Education, Vol. 62, pp.1415.

Lembaga Kerjasama (LKS) UMY. (2018). Desain Aktivitas Internasionalisasi LKS UMY. Yogyakarta: Universitas Muhammadiya Yogyakarta (UMY).

Marshall, Monty, G., \& Keith Jaggers. (2002). Polity IV Project (Political Regime Characteristics and Transitions, 1800-2002): Dataset Users' Manual. University of Maryland, Maryland.,

Muktiyanto, Ali. (2016). Good University Governance dan Kinerja Program Studi: Pengaruh Penerapan Akuntansi Manajemen, Teknik Manajemen dan Pilihan Prioritas Strategi Sebagai Model Mediasi Fit. Disertasi, Fakultas Ekonomi dan Bisnis Program Pascasarjana, Universitas Indonesia, Depok.

Osborne, Michael J. (2003). Internationalisation, Globalisation \& Universities. Dapat diakses pada https://bhert.com/events/2003-11-

25/MichaelOsborne.pdf [Diakses pada 17 April 2018].

Pietrucha, J. (2017). Country-specific determinants of world university rankings. Scientometrics, Vol. 114, No. 3, pp.1129-1139.

Porsteinsson, B. (2010). Internationalisation In Higher Education. Dapat diakses pada https://slideplayer.com/slide/4220115/ [Diakses pada 22 Maret 2018].

Pratolo, S., Jatmiko, B., \& Manuhara, W. (2015). Good University Governance dan Kinerja-PT: Model Pemetaan dan Perancangan Kinerja-PT Melalui Kualitas dan Kompetensi Lulusan, Pelayanan Serta Daya Saing Menuju Kualitas Lulusan dan World Class University. Akmenika (Jurnal Akuntansi dan Manajemen), Vol. 12, No. 1, pp. 540-562.

Ristekdikti. (2018). Laporan Tahunan Kementrian Riset, Teknologi, dan Pendidikan Tinggi Tahun 2017. Dapat diakses pada https://ristekdikti.go.id/wpcontent/uploads/2018/05/20180508-Layout-Buku- 
Laporan-Tahunan-2017.pdf [Diakses pada 11 Juni 2018].

Rosyidi, Sri Atmaja P. (2015). Penguatan Kapasitas Internasionalisasi UMY. UMY, Yogyakarta.

Salter, B., \& Tapper, T. (2002). The External Pressures on the Internal Governance of Universities. Higher Education Quarterly, Vol. 56 (3), pp. 245256.

Scott, P. (2000). Higher Education Re-formed. Falmer Press, London and New York.

Shattock, M. (2006). Managing Good Governance In Higher Education. McGraw-Hill Education, UK.

Shin, J. C., \& Harman, G. (2009). New Challenges For Higher Education: Global And Asia-Pacific Perspectives. Asia Pacific Education Review, Vol. 10, pp.1-13.

Shin, J. C., Robert K, T., \& Teichler, U. (2011). University Rankings: Theoretical Basis, Methodology and Impacts on Global Higher Education. Springer, Netherlands.

Transparency International. (2019). Corruption Perceptions Index 2018. Berlin: Transparency International.

United Nations Development Programme (UNDP). (1997). Governance for Sustainable Human Development: A UNDP Policy Document. New York: United Nations Development Programme.

Universitas Muhammadiyah Yogyakarta (UMY). (2018). Capaian Internasionalisasi UMY. UMY, Yogyakarta. 